\title{
En metasyntese af vejledning i læreruddannelser i Norden
}

\author{
Karen Annette Paaske, lektor, ph.d. og programkoordinator, kpa@via.dk \\ Lisbeth Lunde Frederiksen, ph.d. og forsknings-og udviklingsleder, lluf@via.dk \\ Dorthe Busk Mølgaard, lektor, studievejleder og videnmedarbejder, dmol@via.dk \\ VIA University College
}

\begin{abstract}
Resumé
Artiklen er resultatet af en metasyntese om viden om vejledning i nordiske læreruddannelser, udarbejdet fra artikler omhandlende forsknings- og udviklingsarbejder i udvalgte databaser. Forskningsspørgsmålet: Hvilken samlet evident forsknings- og udviklingsviden findes om vejledning i nordiske læreruddannelser fra 2008-2014? Hvilke typer af vejledning er beskrevet i relation hertil? 9 ud af 13 artikler blev inkluderet ud fra en kvalitetsvurdering. Den fundne viden handler primært om praktikvejledning. Forskningsviden om vejledning i andre uddannelseskontekster fx karrierevejledning er nærmest fraværende.Metasyntesen viser, at det at kunne praktikvejlede til fortsat professionel udvikling kalder på flere kompetencer og viden, end aktuel praksis viser.
\end{abstract}

\section{Nøgleord}

Vejlederkompetencer, praktikvejledning, vidensbaseret vejledning, litteratursøgning, læreruddannelse

\section{Artiklen er fagfællebedømt}

\section{Indledning}

Vejledning griber om sig på stadig nye områder (Skagen, 2013).Undervisere vejleder mere og mere, og undervisning som formidling erstattes af vejledning (Plant, 2014). Af studieordninger for læreruddannelsen i Danmark fremgår forskellige vejledningsaktiviteter: praktikvejledning, studie-og karrierevejledning og faglig vejledning, herunder bachelorvejledning (Uddannelses- og Forskningsministeriet, 2015; VIA University College, 2015).

Ph.d. Birte Kaiser skriver: "Det ser ud til, at vejledningen lever et usynligt liv i små intime rum på professionshøjskolerne, hvor relationen vurderes som det afgørende parameter for en vellykket vejledning. Det er der

Årg. 2 | nr. 2 | 2017 | Side 62-83 | https://tidsskrift.dk/index.php/SLP/index ISSN: 2445-8538 | For artikler publiceret i LUP tillades at læsere kan downloade, kopiere, distribuere, udskrive, søge eller linke til og citere fra til ethvert lovligt formål. LUP tillader således ikke at læsere bruger artikler eller dele af dem i egne artikler uden at citere, eller på anden vis anvender dem til kommercielle formål. 
ikke meget faglighed i"(Kaiser, 2012, s. 1). Citatet peger på, at vejledning på professionshøjskoler mere er præget af idéen om den gode relation end af en professionel tilgang på basis af evidens og forskning. Vejledning foregår imidlertid ikke kun på professionshøjskoler; i såvel Danmark som i det øvrige Norden er uddannelsen til lærer opbygget med en vekselvirkning mellem teori og praksis. I et mere internationalt perspektiv findes uddannelser, som ikke på samme vis har denne vekselvirkning mellem teori og praksis på skoler. Derfor er praktikvejledning et særligt felt i læreruddannelser i Norden.

Den norske vejledningsforsker Cato Bjørndal skriver, at selvom vejledning og beslægtede begreber i løbet af de sidste ti år hyppigere anvendes indenfor uddannelsesområdet, er området præget af begrænset empirisk forskning (Bjørndal, 2008). I vejledningsfeltet ses et svagt og ikke særlig udviklet paradigme (Bjørndal, 2010).

Den norske forsker Karen Åberg skriver om vejledningsfeltet:

\begin{abstract}
"utmärkande för kunskapsfältet är att det gemensamma fackspråket är svagt utvecklat och att antalet forskningsstudier är litet. Uppfattningarna om vad handledning är och syftar till skiljer sig åt mellan olika författare, men också mellan handledningens aktörer, dvs handledare, handledda och beställare av handledning." (Åberg, 2009, s. 72)
\end{abstract}

Vejledning er karakteriseret ved mangel på forskning og et fælles, veludviklet fagsprog. Der er enighed om, at vejledning generelt bliver udvidet i omfang, samtidig med at der er mangel på evident viden om vejledning (Bjørndal, 2008; Ulvestad, 2014). Den engelske forsker C. Feltham føjer til dette, at vejledning i højere grad underbygges med følelsesmæssig retorik end med forskningsmæssigt belæg (Feltham, 2013).

Vejledning er et samlebegreb, som omfatter dels virksomhed inden for forskellige kontekster og arbejdssammenhænge, dels en række forskellige traditioner og retninger, fx opererer den norske vejledningsforsker Kaare Skagen med ti vejledningsretninger (Skagen, 2013). Kernen i retningerne er knyttet til vejledningens formål, som er formidling af viden, visning af eksempler, refleksion sammen med andre, klarlæggelse af sagsforhold og at finde handlemuligheder til læring og personlig udvikling. En forståelse af vejledning kan være: "samtaler mellom en veileder og en eller få veisøkere, 
som har noenlunde felles formål om a fremme veisøkers læring, utvikling eller problemhåndtering" (Bjørndal, 2008, s. 28).

Der har gennem tiden været forskellige holdninger til professionalisering af vejledningsområdet. Vejledning er gennem årene søgt professionaliseret bl.a. i Danmark gennem vejledningsreformen (Undervisningsministeriet, 2003), men udgør stadig ikke en profession, da mange beskæftiger sig med vejledning uden en speciel uddannelse og kun som en del af en anden profession. Norsk forsker Asbjørn K. Ulvestad diskuterer, om det er eftertragtelsesværdigt alene at stræbe mod at blive en profession, da vejledning altid drejer sig om mere end en profession. Vejledning handler også om erhvervsudøvelse og problemløsning i samarbejde med andre erhvervsgrupper (Ulvestad, 2014).

En af de største professionsuddannelser i Danmark er læreruddannelsen, som må forventes at være på forkant, når det gælder didaktik, pædagogik og vejledning, og dermed funderet på forskningsbaseret viden. Det er derfor interessant at undersøge, hvilken viden der findes om vejledning i læreruddannelsen, og vurdere evidensen af denne viden. For at opnå en vis bredde i undersøgelsen inddrages forskning fra andre nordiske lande, som er sammenlignelig med dansk pædagogisk tradition. Det handler om en nordisk tilgang, der rummer mere end de angelsaksiske og kontinentale traditioner (Schnack, 1994; Wiberg, 2017).

Artiklen bygger på en metasyntese (Sandelowski \& Barroso, 2007), som er udarbejdet på baggrund af artikler omhandlende forsknings- og udviklingsarbejder. Artiklerne inkluderes, hvis de handler om vejledning i læreruddannelsen.

Forskningsspørgsmålet har været: Hvilken samlet evident forsknings- og udviklingsviden findes om vejledning i læreruddannelsen i Norden i perioden 2008 til 2014, og hvilke typer af vejledning er beskrevet i relation hertil?

\section{Formål og metode}

Det er artiklens formål at præsentere resultatet af en metasyntese om viden om vejledning i læreruddannelserne i Norden.

Metasyntesen falder i tre dele; først en kvalitetsvurdering af artiklerne, hvor evidensen vurderes. Dernæst en sammenlignende vurdering af artiklerne og udledning af tematikker. Endelig en syntese med afsæt i de udledte tematikker fra artiklerne. 
Paaske, Frederiksen og Mølgaard: En metasyntese af vejledning i læreruddannelser ...

Metodisk vælges en kvalitativ metasyntese, som er inspireret af de metodiske retningslinjer hos Sandelowski og Barroso (Sandelowski \& Barroso, 2007). I metasyntesen udvikles ny kvalitativ viden på baggrund af fortolkninger af udvalgte og formålsrettede artikler. Kvalitativ metasyntese betragtes som en relativt ny metodologi (Levack, 2012). En metasyntese sammenbringer studier indenfor beslægtede områder, her vejledning i læreruddannelsen, hvilket giver mulighed for at forklare den samlede viden på nye måder og dermed giver ny indsigt (Walsh \& Downe, 2005). Metasyntesen fremkommer gennem tolkninger af andres resultater og er en opsummering af andres viden samt udvikling af ny viden. Artiklens forfattere planlagde en søgestrategi med valg af nordiske og internationale pædagogiske databaser og med brug af danske, svenske, norske og engelske søgeord.

\section{Litteratursøgning}

Der blev i april/maj 2014 foretaget en kritisk systematisk litteratursøgning i nordiske forskningsartikler fra perioden 2008-2014 i databaserne ERIC, IDUNN, Dansk Clearinghouse, NorArt og ProQuest. Inklusionskriterierne var peer-reviewede studier publiceret på dansk, svensk, norsk og engelsk.

I ERIC var søgeordene: teacher education, counselling, supervisning, mentoring in education, Iceland, Sweden, Norway, Denmark og Finland i kombinationer med AND/OR.

I IDUNN, Dansk Clearinghouse, NorArt og ProQuest var søgeordene veiledning, lærerutdann, teacher education, mentor, mentoring, counselor, counselling, Denmark, Norway, Sweden, Finland og Iceland i kombinationer med AND/OR.

De fundne forskningsartikler blev vurderet og inkluderet ud fra forskningsspørgsmålet. Artikler om vejledning i andre kontekster end læreruddannelsen blev ekskluderet.

Litteratursøgningen resulterede i 13 relevante artikler vurderet ud fra fuld tekst. Både kvalitative og kvantitative undersøgelser blev inkluderet for at give et mere nuanceret billede af forskningen på området. Artiklerne blev grupperet ud fra deres forskningsmetode (Walsh \& Downe, 2005). Der var én kvantitativ artikel og 12 kvalitative artikler.

Kvaliteten af den viden, der er fundet i de 13 artikler, blev vurderet ud fra tjeklister, som omtales nærmere nedenfor. Alle undersøgelser i de 13 artikler bidrog på forskellig vis og med forskellig videnskabelig evidens til vores forståelse af vejledningsfeltet. 


\section{Metode del 1 - evidensvurdering}

Alle inkluderede artikler blev kvalitetsvurderet i forhold evidensen ud fra følgende karakteristika: Troværdighed, transparens og graden af metodologisk refleksion (Tanggaard, 2015). Den specifikke systematik ved vurderingsarbejdet blev bestemt af den enkelte undersøgelses forskningsmetode. Der blev udarbejdet tjeklister (Walsh \& Downe, 2005) til vurderingsarbejdet, hvorved en kritisk gennemgang af de individuelle studiers metodiske og teoretiske grundlag blev dokumenteret. Vi udarbejdede én tjekliste til kvalitative artikler og en anden til den kvantitative artikel.

\section{Tjekliste til evidensvurdering af kvantitativ undersøgelse}

Den kvantitative forskningsartikel (Ohnstad \& Munthe, 2008) er en spørgeskemaundersøgelse. Spørgeskemaundersøgelser rangerer relativt lavt i evidenshierarkiet (Roecker, 2012), men der er udarbejdet en alternativ forståelse af evidens, hvor forskningsmetoder grupperes efter, hvad de er gode til at sige noget om, og hvor gode de forskellige undersøgelsesdesign er til at besvare forskningsspørgsmålet (Thomsen \& Dahlerup, 2008). Denne forståelse danner grundlag for at udvikle en kvalitetsvurdering, hvori der indgår undersøgelse af systematikken i dataindsamlingen, af åbenheden om inklusionskriterier og af omhyggelighed ved anvendelsen af metode. Billhult og Gunnarsson (2014) arbejder inden for kvantitative undersøgelsesdesign med spørgeskemaundersøgelser. De har udfærdiget en tjekliste til at vurdere kvaliteten af en spørgeskemaundersøgelse med fokus på validitets- og reliabilitetskriterier. Der kan udledes fire kvalitetskriterier: 1. Tydelig metodebeskrivelse: Er der transparens? 2. Validering af spørgeskemaundersøgelsen: Ses en kobling mellem formål og metode? 3. Spørgeskemaundersøgelsens reliabilitet: Er der en reliabilitetstest? 4. Anvendelse, diskussion og konklusion: Diskuteres resultaternes anvendelighed? Er konklusionen troværdig? (Billhult \& Gunnarsson, 2014).

Ud fra ovenstående kvalitetskriterier vurderes Ohnstad \& Munthes artikel (2008) at være af høj kvalitet.

\section{Tjekliste til evidensvurdering af kvalitative undersøgelser}

Der er fundet 12 kvalitative artikler, som benytter forskellige dataindsamlingsmetoder som casestudier, interviews, observationer og aktionsforsk- 
Paaske, Frederiksen og Mølgaard: En metasyntese af vejledning i læreruddannelser ...

ning. Kvalitative design rangerer som spørgeskemaundersøgelser lavt i evidenshierarkiet (Roecker, 2012). Vi arbejdede med en alternativ forståelse af evidens, hvor forskningsmetoder grupperes efter, hvad de er gode til at sige noget om, og hvor gode de forskellige undersøgelsesdesign er til at besvare forskningsspørgsmålet (Thomsen, \& Dahlerup, 2008). Systematikken for kvalitetsvurderingen tager udgangspunkt i Peter Dahler-Larsens kvalitetskriterier i kvalitative undersøgelser (Dahler-Larsen, 2008). Han påpeger, at kvalitetskriterier i kvalitative undersøgelser kan have en institutionel forankring, uden at det styrker deres evidens fra et videnskabeligt synspunkt, og fremhæver derfor en håndværksmæssig validitet, som handler om kyndighed i håndtering af kvalitativ metode i forhold til materialet (Dahler-Larsen, 2008, s. 19). Er metoderne udmøntet på forsvarlig vis i forhold til undersøgelsesfeltet, og færdiggøres arbejdet? En undersøgelse af god kvalitet har ofte en kritisk tilgang, og det primære vil være intern validering. Der er tre kvalitetskriterier: 1 . Kommunikativ validitet: Opererer undersøgelsen med korrekt forståelse af informanternes egne kategorier (førsteordenskonstruktioner)? 2. Transparens: Er fremgangsmåderne i undersøgelsen tydelige? 3. Det heuristiske kriterium: Fremføres ny viden, nye indsigter og perspektiver? (Dahler-Larsen, 2008). På denne baggrund vurderes fire artikler som værende af høj kvalitet (Gloppen, 2013; Nilssen, 2010b; Solstad, 2010; Ottesen \& Jahreie, 2010), og fire artikler vurderes som værende af middel kvalitet (Eriksson, 2013; Solstad, 2013; Atjonen, 2012; Nilssen, 2010a).

Evidensvurderingerne er foretaget ud fra en evidenstypologi, hvor de forskellige forskningsmetoder ikke rangordnes; der er i stedet foretaget en bredere og mere nuanceret vurdering af kvaliteten af de konkrete undersøgelsesmetoder. Evidensvurderingen er foretaget $\mathrm{i}$ en konsensusdiskussion forskerne imellem. Alle artikler, der vurderes med middel eller høj kvalitet, inkluderes. Det førte til i alt ni inkluderede artikler.

\section{Metode del 2 - sammenligning og udledning af tematikker}

Andet trin var en sammenlignende vurdering af artiklerne og udledning af tematikker. Først blev formålene med artiklerne sammenlignet med henblik på at afdække, hvilket vejledningsområde artiklerne handlede om, dernæst vurderedes metoder og studiernes omfang (se Tabel 1). Selvom artiklerne er forskellige i metoder og omfang, vurderes det, at artiklernes resultater kan indgå i en metasyntese (Willman \& Stoltz, 2014). 


\begin{tabular}{|l|l|l|l|}
\hline $\begin{array}{l}\text { Kvantita- } \\
\text { tiv artikel }\end{array}$ & Formål & Metode & Studiets omfang \\
\hline $\begin{array}{l}\text { (Ohnstad } \\
\text { \& Munthe, } \\
\text { 2008) }\end{array}$ & $\begin{array}{l}\text { At undersøge, hvordan prak- } \\
\text { tiklærere rapporterer dels om } \\
\text { holdninger og erfaringer med at } \\
\text { være praktikskole, og dels om } \\
\text { samarbejdet omkring vurdering } \\
\text { og samarbejdet med høgskola/ } \\
\text { universitet om praktiklæring. }\end{array}$ & $\begin{array}{l}\text { Spørgeskema- } \\
\text { undersøgelse }\end{array}$ & $\begin{array}{l}2.205 \text { lærere ved } \\
111 \text { praktikskoler }\end{array}$ \\
\hline
\end{tabular}

\begin{tabular}{|l|l|l|l|}
\hline $\begin{array}{l}\text { Kvalitative } \\
\text { artikler }\end{array}$ & Formål & Metode & Studiets omfang \\
\hline $\begin{array}{l}\text { (Eriksson, } \\
\text { 2013) }\end{array}$ & $\begin{array}{l}\text { At undersøge, om gruppevejled- } \\
\text { ningssamtaler faciliterer stude- } \\
\text { rendes teori-praksiskobling. }\end{array}$ & Skr. Evaluering & $\begin{array}{l}\text { 103 lærerstude- } \\
\text { rende }\end{array}$ \\
\hline $\begin{array}{l}\text { (Solstad, } \\
\text { 2013) }\end{array}$ & $\begin{array}{l}\text { At undersøge, om studerende } \\
\text { făr erfaringer med kritisk og } \\
\text { professionsrettet refleksion i } \\
\text { praktikvejledning. }\end{array}$ & $\begin{array}{l}\text { Spørgeskema- } \\
\text { undersøgelser }\end{array}$ & $\begin{array}{l}\text { 34 lærerstude- } \\
\text { rende gennem } \\
\text { fire spørgerun- } \\
\text { der }\end{array}$ \\
\hline $\begin{array}{l}\text { (Gloppen, } \\
\text { 2013) }\end{array}$ & $\begin{array}{l}\text { At undersøge hvordan treparts- } \\
\text { samtalen er led i kvalitetssikring } \\
\text { af sammenhæng mellem stu- } \\
\text { derendes praktik og højskolens } \\
\text { teoriundervisning. }\end{array}$ & $\begin{array}{l}\text { Aktionsforsk- } \\
\text { ningsprojekt } \\
\text { med observatio- } \\
\text { ner og skriftlige } \\
\text { evalueringer }\end{array}$ & $\begin{array}{l}\text { 76 lærerstude- } \\
\text { rende fra 16 } \\
\text { praktikgrupper }\end{array}$ \\
\hline $\begin{array}{l}\text { (Atjonen, } \\
\text { 2012) }\end{array}$ & $\begin{array}{l}\text { At undersøge studerendes ople- } \\
\text { velser af etiske aspekter ved } \\
\text { praktikvejledning. }\end{array}$ & $\begin{array}{l}\text { Spørgeske- } \\
\text { maundersøgelse }\end{array}$ & $\begin{array}{l}\text { 201 lærerstude- } \\
\text { rende }\end{array}$ \\
\hline $\begin{array}{l}\text { (Solstad, } \\
\text { 2010) }\end{array}$ & $\begin{array}{l}\text { At undersøge, hvordan stude- } \\
\text { rende oplever teori-praksisfor- } \\
\text { holdet efter en praktikperiode. }\end{array}$ & $\begin{array}{l}\text { Spørgeskema- } \\
\text { undersøgelser } \\
\text { og fire enkelt- } \\
\text { interviews }\end{array}$ & $\begin{array}{l}\text { 34 lærerstude- } \\
\text { rende gennem } \\
\text { fire spørgerun- } \\
\text { der }\end{array}$ \\
\hline $\begin{array}{l}\text { (Nilssen, } \\
\text { 2010b) }\end{array}$ & $\begin{array}{l}\text { At afdæke én praktikvejleders } \\
\text { ageren under en vejlednings- } \\
\text { samtale og vejlederens refleksi- }\end{array}$ & $\begin{array}{l}\text { Casestudie } \\
\text { med logbøger, } \\
\text { interviews samt } \\
\text { lyd- og video- } \\
\text { optagelser }\end{array}$ & $\begin{array}{l}\text { lærerstude- } \\
\text { rende gennem } \\
\text { en seks ugers } \\
\text { periode }\end{array}$ \\
\hline $\begin{array}{l}\text { at afdæker én praktikvejleders } \\
\text { samtale og vejlederens refleksi- } \\
\text { oner og tanker under samtalen. }\end{array}$ & $\begin{array}{l}\text { Casestudie } \\
\text { med logbøger, } \\
\text { interviews samt } \\
\text { lyd- og video- } \\
\text { optagelser }\end{array}$ & $\begin{array}{l}\text { 5 lærerstude- } \\
\text { rende gennem } \\
\text { en seks ugers } \\
\text { periode }\end{array}$ \\
\hline
\end{tabular}




\begin{tabular}{|l|l|l|l|}
\hline $\begin{array}{l}\text { (Ottesen } \\
\text { \& Jahreie, } \\
\text { 2010) }\end{array}$ & $\begin{array}{l}\text { At afdække, hvordan læring } \\
\text { konstrueres og udvikles, samt } \\
\text { hvordan studerendes positioner } \\
\text { i forskellige praksisser træder } \\
\text { frem i deres beskrivelser. }\end{array}$ & $\begin{array}{l}\text { Videooptagelser. } \\
\text { Skr. evalueringer } \\
\text { Vurderingsrap- } \\
\text { porter }\end{array}$ & $\begin{array}{l}190 \text { lærerstude- } \\
\text { rende }\end{array}$ \\
\hline
\end{tabular}

Tabel 1

Det er interessant, at otte af de inkluderede artikler handler om praktikvejledning og teori-praksis-forholdet. Kun én artikel handler om, hvorledes læring konstrueres. Det betyder, at den viden, der er fundet om vejledning, primært handler om praktik og om teori-praksis-forholdet. De andre vejledningsområder: studie-og karrierevejledning, bachelorvejledning og faglig vejledning er ikke belyst i de ni artikler. Det vurderes, at denne begrænsning til praktik og teori-praksis-forhold ikke kan tilskrives søgningen, hvilket uddybes i diskussionen.

\section{Tematisk vurdering}

Med det formål at samle forsknings- og udviklingsviden om vejledning i læreruddannelsen i Norden, blev der foretaget en meningskondensering af artiklernes resultater, hvor betydningsenheder blev formuleret i temaer i vejledning (Kvale \& Brinkmann, 2009). Se tabel 2 og tekst om tematikker herunder.

\begin{tabular}{|c|c|c|c|c|c|c|}
\hline $\begin{array}{l}\text { Tema- } \\
\text { tikker i } \\
\text { artiklerne }\end{array}$ & $\begin{array}{l}\text { Vejleder- } \\
\text { kompe- } \\
\text { tence og } \\
\text {-rolle }\end{array}$ & $\begin{array}{l}\text { Relation } \\
\text { og asym- } \\
\text { metri }\end{array}$ & $\begin{array}{l}\text { Reflek- } \\
\text { sion og } \\
\text { refleksi- } \\
\text { onsrum }\end{array}$ & Etik & Samtalen & $\begin{array}{l}\text { Rammer } \\
\text { og } \\
\text { indhold }\end{array}$ \\
\hline $\begin{array}{l}\text { (Ohnstad } \\
\text { \& Munthe, } \\
\text { 2008) }\end{array}$ & $x$ & & & & & $x$ \\
\hline $\begin{array}{l}\text { (Eriksson, } \\
2013 \text { ) }\end{array}$ & & & $x$ & & $x$ & \\
\hline $\begin{array}{l}\text { (Solstad, } \\
\text { 2013) }\end{array}$ & $x$ & & $x$ & & & \\
\hline $\begin{array}{l}\text { (Gloppen, } \\
\text { 2013) }\end{array}$ & $x$ & $x$ & $x$ & $X$ & & $x$ \\
\hline
\end{tabular}




\begin{tabular}{|c|c|c|c|c|c|c|}
\hline $\begin{array}{l}\text { (Atjonen, } \\
2012 \text { ) }\end{array}$ & $X$ & $X$ & & $X$ & & $X$ \\
\hline $\begin{array}{l}\text { (Solstad, } \\
\text { 2010) }\end{array}$ & $X$ & $X$ & $X$ & & & $X$ \\
\hline $\begin{array}{l}\text { (Nilssen, } \\
2010 b)\end{array}$ & $X$ & $X$ & & & $X$ & $X$ \\
\hline $\begin{array}{l}\text { (Nilssen, } \\
\text { 2010a) }\end{array}$ & $X$ & $X$ & $X$ & & $X$ & \\
\hline $\begin{array}{l}\text { (Ottesen } \\
\text { \& Jahreie, } \\
\text { 2010) }\end{array}$ & $X$ & $X$ & $X$ & $X$ & & $X$ \\
\hline $\begin{array}{l}\text { Optræder } \\
\text { i alt } \\
\text { (antal } \\
\text { gange) }\end{array}$ & 8 & 6 & 6 & 3 & 3 & 6 \\
\hline
\end{tabular}

Tabel 2

\section{Vejlederkompetencer og -rolle}

Forskningsresultater fra Solstad og Gloppen (Solstad, 2013; Solstad, 2010; Gloppen, 2013) viser, at praktikvejlederne er udfordret i deres ageren som vejleder og deres forståelse af vejlederrollen. Studerende efterlyser, at praktikvejledere har en øget bevidsthed om og mod på at indgå i et refleksionsrum med studerende. Nilssens (2010a; 2010b) studier peger på, at praktikvejledere optræder som undervisere med ledende spørgsmål og irettesættelse af de studerende. I Ohnstad \& Munthes (2008) studie angiver praktikvejledere, at deres identitet mest er knyttet til at være lærer for elever i skolen frem for at være praktikvejleder for studerende. Denne udfordring tydeliggøres i Ottesen \& Jahreie's (2010) studie om praktikvejlederens tvetydige position: vejlederrollen i forhold til studerende og underviser for elever. Der efterlyses således kompetencer til at vejlede studerende mere end at være lærer for eleverne i skolen. Der ønskes en vejlederrolle, hvor vejleder er villig til at skabe et refleksionsrum med studerende, hvor vejleder ikke irettesætter studerende og ikke stiller ledende spørgsmål.

\section{Relation og asymmetri}

Dette tema fokuserer på relationen mellem studerende og praktikvejleder, hvor praktikvejlederen især optræder i en asymmetrisk position. Den asymmetriske position afdækkes i Ottesen og Jahreie's (2010) omfattende 
forskningsarbejde, som viser, at praktikvejlederen er optaget af at regulere studerendes mentale processer og forventer, at de studerende følger vejlederens direktiver. Atjonen (2012) og Nilssens (2010a; 2010b) studier viser ligeledes en praktikvejleder, som forventer, at studerende opfylder vejlederens mål og tilsidesætter egne meninger og erfaringer. Vejleder er dominant styrende i vejledningen (Atjonen, 2012; Nilssen, 2010a; Nilssen, 2010b).

\section{Refleksion og refleksionsrum}

Refleksionsrummet i praktikvejledning er især praksisorienteret. Solstads (2013) forskningsresultater tydeliggør, at gode råd og opmuntring optræder frem for kritisk refleksion, udfordringer og teoribaserede argumenter. Efterrefleksion har forrang for før-refleksion, og vejleder fokuserer på, hvad de studerende burde have gjort (Solstad, 2013; Solstad, 2010). I Solstads (2010) forskning optræder kun ganske få studerende, som refererer til, at praktiklærere udfordrer til professionsorienteret refleksion. Forskningen viser, at faglige diskussioner med medstuderende understøtter refleksioner og teoribaserede valg frem for vejledning med praktikvejlederen (Solstad, 2010). I gruppevejledning faciliteres de studerendes teori-praksis-kobling med beskrivelser af pædagogiske processer. Her er medstuderende gode bidragydere ved refleksionsarbejdet (Eriksson, 2013). Studerende oplever facilitering af deres refleksioner gennem praktikvejlederens åbne spørgsmål (Gloppen, 2013). Refleksion og refleksionsrum er primært et område og et rum, som præges af peer-to-peer-vejledning, hvor refleksion med en vejleder optræder mere sparsomt.

\section{Etik}

Atjonens (2012) undersøgelse af studerendes oplevelser af etiske aspekter ved praktikvejledning viser, at god etisk vejledning er dialogisk og omhandler feedback med en lyttende og støttende vejleder, der er mentalt til stede. Modsat opleves en autoritær praktikvejleder som en, der ikke udviser respekt og tolerance (Atjonen, 2012). Etikken italesættes i dels Ottesen \& Jahreie's (2010) undersøgelse, hvor underviserne fra Høgskolan er optaget af at regulere de studerendes mentale processer og ikke er lyttende vejledere, og dels i Gloppens (2013) undersøgelse af trepartssamtalen, hvor vejledernes udvisning af omsorg kan understøtte studerendes refleksionsrum. Etikken fordrer en dialogisk og ikke-regulerende adfærd fra vejlederens side, hvor omsorg for den studerende kan understøtte den studerendes refleksionsrum. 


\section{Samtalen}

Nilssens (2010a; 2010b) casestudier af én praktikvejleders ageren under en vejledningssamtale viser en ikke-åben samtale, en samtale med ledende spørgsmål og irettesættelser, som mere minder om en undervisningslektion (Nilssen, 2010a; Nilssen, 2010b). Erikssons (2013) analyse af 103 refleksionsopgaver fra studerende på sidste semester viser, at gruppesamtaler kan udvikle studerendes teori-praksis-koblinger (Eriksson, 2013). Forskningen viser, at gruppesamtaler og en åben samtale uden irettesættelser støtter studerendes mulighed for at koble teori og praksis.

\section{Rammer og indhold}

Uklare rammer og uklare roller mellem praktikvejleder og undervisere fra Høgskolan skaber forskellige forventninger til og mål med vejledningssamtalerne, hvilket hæmmer de studerendes praktikarbejde (Ottesen \& Jahreie, 2010). Det underbygges af Gloppens (2013) resultater, som viser, at fælles begreber og forståelsesgrundlag kan bidrage til en kvalificering af vejledningssamtalerne. Uklarheder omkring praktikvejledernes opgaver fremgår af Ohnstad \& Munthes (2008) undersøgelse af 2.205 praktikvejledere ved 111 praktikskoler, hvor $40 \%$ oplever, at de står alene med vurderingsopgaven af de studerende. Solstads (2013; 2010) og Nilssens (2010a; 2010b) undersøgelser viser ligeledes uklarheder omkring indholdet i praktikvejledningen. Det betyder, at klare rammer, rolleafklaring, fælles begreber og fælles forståelsesgrundlag mellem praktikvejleder og underviser fra Høgskolan kan skabe fælles forventninger til mål med vejledningssamtaler og dermed støtte studerendes praktikarbejde.

\section{Sammenfatning af tematisk vurdering}

Tematikker optræder, som det fremgår af tabel 2, ikke med lige stor vægt. Vejlederkompetence og -rolle optræder hyppigst, hvilket begrunder valg af dette område til metodedel 3 , hvor vi syntetiserer ved at belyse med yderligere teori. Vejlederkompetence og -rolle er nært knyttet til det at være professionel. At initiere refleksion i vejledning er et centralt kompetenceområde for en vejleder, når det handler om uddannelse og læring. Samtidig viser tabel 1, at den fundne viden om vejledning primært bygger på forskning, hvor praktikvejledning er omdrejningspunktet, hvilket vi derfor også vil fokusere på i syntesen. 
Paaske, Frederiksen og Mølgaard: En metasyntese af vejledning i læreruddannelser ...

\section{Metode del 3 - syntese}

Praktikvejledning og vejlederkompetencer med relevante underkategorier vil i dette tredje trin af metasyntesen skabe fokus i det fortsatte arbejde (Tingleff, Rossen, \& Buus, 2010).

\section{Professionel udvikling og refleksion}

Vejlederkompetencer skal ses i lyset af hensigten med vejledning: at støtte den lærerstuderendes professionelle udvikling - også i praktikforløb. Centrale aspekter af betydning for optimal professionel udvikling er: udvikling af faglig nysgerrighed og videbegær, en vedvarende kundskabssøgende holdning, en åbenhed for teori samt en forståelse af og bevidsthed om kompleksitet i det professionelle arbejde (Rønnestad, 2008). Rønnestad fremhæver vigtigheden af tolerancen over for flertydighed og evnen til at forholde sig til sammensatte og komplekse problemstillinger i professionen. Det mest centrale enkeltstående aspekt ved professionel udvikling er ifølge Rønnestad at kunne opretholde en kontinuerlig refleksion, når man møder udfordringer, og det uanset niveauer af professionel erfaring. Rønnestad pointerer endvidere med henvisning til Chin og Benne (1969) og Korthagen og Wubbels (1995), at professionelle forandringer sker gennem refleksion over praksis, og opfattelser formes og ændres både i det reflekterende enerum og i dialog.

Refleksion kan føre til professionel udvikling (Rønnestad, 2008), der igen kan føre til selvtillid (Korthagen \& Wubbels, 1995). Det må derfor være praktikvejlederens opgave at øge den studerendes handlemuligheder ud fra dennes egne præmisser gennem refleksion. Korthagen \& Wubbels (1995) definerer refleksion som: "the mental process of structuring or restructuring an experience, a problem or existing knowledge or insights" (Korthagen \& Wubbels, 1995, s. 193). Deres forskning viser, at reflekterende lærerstuderende opnår en stærkere følelse af selvtillid, hvilket betyder, at de fokuserer på deres undervisning og ikke på sig selv som lærere.

Derudover peger Jank \& Meyer (1997) på, at en reflekterende arbejdsmåde kan udvikle evnen til at analysere og vurdere forskellige praktiske handlingsalternativer og på den måde bidrage til udvikling af professionel kompetence. Det gælder både for vejlederes og studerendes udvikling af professionelle kompetencer (Jank \& Meyer, 1997).

\section{Vejledning og dialog}

Vejledningsfeltet rummer mange modeller og dermed mange retninger og begreber. Derfor kan vejledning anskues i mange forskellige teoretiske per- 
spektiver (Skagen, 2013) fx konstruktivistiske. Vejledning baseret på et konstruktivistisk læringssyn findes hos Heikkinen, Jokinen \& Tynjälä (2008), som peger på, at vejledning af nyuddannede lærere i langt højere grad synes at føre til refleksioner og professionel udvikling, hvis vejledningen baseres på et konstruktivistisk læringssyn med fokus på dekonstruktion og rekonstruktion af viden og praksis ud fra erfaringer med praksis tilføjet et sociokulturelt perspektiv (Heikkinen, Jokinen \& Tynjälä, 2008). Ud fra denne vinkel er det vigtigt for refleksionen, at den vejledte kan formulere en faglig forståelse i ord, dele den med andre med henblik på respons og dermed kunne drøfte såvel det, man forstår, som det, man ikke forstår. Sproget kan i denne sammenhæng ses som en åbning eller kobling mellem det indre og det ydre; mellem tænkningen og kommunikationen med andre. Refleksion handler om at lære. Ifølge Bakhtin sker læring altid i interaktion, og dialogen er væsentlig i en personlig tilegnelse af stof (Dysthe, 2003). Dialogen faciliterer konstruktionsprocesser i forhold til allerede erfaret og konstrueret viden, dialogen personliggør indholdet, og igennem dialogen konstitueres meningen (Dysthe, 2003).

Vejledning er en dialogisk virksomhed, hvor vejlederen befinder sig i konstant dialog med den vejledningssøgende. Samtalen drejer sig om at opnå forståelse, lytte, være empatisk og forberedt på at lade sig ændre (Peavy, 2006), og det betyder, at centrale vejlederkompetencer er at være undersøgende, udforskende og lyttende (Skagen, 2013).

\section{Lærerstuderendes perspektiv på læring}

I et forskningsprojekt omhandlende, hvad lærerstuderende opfatter som vigtigt på læreruddannelsen (Frederiksen, 2013), fremgår det, at mange af de studerende fremhæver kompetencer til at kunne reflektere og forholde sig analytisk til praksis. De har for øje, at de ikke blot skal tilegne sig teori og heller ikke blot lære, hvordan teorier kan anvendes i praksis, men at de, som Smeby (2008) anfører, skal lære at se udfordringerne fra praksis i et teoretisk og analytisk perspektiv. Ligeledes udtrykker de studerende vigtigheden af at tilegne sig analytiske kompetencer. De taler i den sammenhæng om evnen til at kunne reflektere, begrunde og legitimere på planlægnings-, gennemførelses - og vurderingsniveau (Frederiksen, 2013). På baggrund af læsningen af de udvalgte artikler tyder det på, at vejlederne i praktikken ikke har fokus på refleksion og argumentation i deres vejledning, og intet tyder på, at vejlederne har kompetencer inden for dette. 
Paaske, Frederiksen og Mølgaard: En metasyntese af vejledning i læreruddannelser ...

\section{Vejledning og rådgivning i praktikken}

Ohnstad og Munthe (2008) skriver, at $74 \%$ af praktikvejlederne "oplever sin profesjonelle identitet å være mest knyttet til det å være lærere for elever" (Ohnstad \& Munthe, 2008, s. 477). En kompetent vejleder skal ifølge praktikvejledere primært kunne praktisere sit fag i skolen. Nilssen (2010a; 2010b) finder i sine undersøgelser, at praktikvejledere optræder som undervisere med ledende spørgsmål og irettesættelser: "she explains how they [the student] should learn from my reasoning" (Nilssen, 2010b, s. 437). Og Solstad (2010; 2013) påpeger, hvorledes rådgivning har forrang i praktikvejledningen. En praktikvejleder giver gode råd, opmuntrer og eftervejleder med fokus på, hvad studerende bør forandre. I Solstads (2010; 2013) undersøgelser oplever enkelte studerende dog, at praktikvejledere opfordrer til professionsorienteret refleksion, men initiering af refleksion er ikke det fremherskende i praktikvejledning (Solstad, 2010; Solstad, 2013).

I et vejledningsforhold med en god relation mellem vejleder og studerende anses råd som en vigtig del af vejledningen (Skagen, 2013). Rådgivning opfattes dog ofte i opposition til vejledning, hvor studerende er mere aktive og opmuntres til at reflektere og selv tage ansvar for at problemløse (Borgen \& Hiebert, 2002; Borgen \& Hiebert, 2006; Paaske, 2010). I rådgivning fokuseres primært på en problemstilling genereret fra et ydre perspektiv, hvor vejlederen foreskriver en handling i relation til et aktuelt problem. Det at rådgive vedrører en information om et bestemt emne, som ikke nødvendigvis behøver at være relateret til den vejledtes udfordringer. Informationens validitet og reliabilitet er afhængig af vejlederens viden, erfaring og råd.

Vejledning i form af rådgivning, som skitseret ovenfor, giver ikke mulighed for eksempelvis en konstruktivistisk forståelse af læring hos den studerende med fokus på dekonstruktion og rekonstruktion af viden og praksis ud fra erfaringer med praksis; derved ekskluderes gode muligheder for refleksion. I dette perspektiv må det anbefales, at råd kun bør udgøre en lille del af vejledningen.

\section{Vejlederkompetencer}

Vejlederkompetencer er ikke en absolut størrelse, men er relative og under stadig udvikling. Kompetencer består af flere ting: 1) Faglig viden eller sagskompetence, som fx er viden om et bestemt genstandsfelt under hensyntagen til den relevante kontekst, den vejledningssøgendes kompetencer samt personlige forudsætninger. 2) Vejledningsfaglig viden og vejledningsmeto- 
Paaske, Frederiksen og Mølgaard: En metasyntese af vejledning i læreruddannelser ...

diske færdigheder. 3) Viden om læring og didaktik (Løve, 1985; Løve, 2005). I både Ohnstad \& Muntes (2008) og i Nilssens (2010a; 2010b) artikler afspejles en forståelse af vejlederkompetencer, især bestående af lærerfaglighed. Vejlederkompetencer vurderes ikke som særlig vigtige. Lauvås og Handal (1997) problematiserer, at vejlederkompetencer "reduceres til et spørgsmål om personlig natur" (Lauvås \& Handal, 1997 s. 58). Ifølge Lauvås og Handal må dette ikke udelukke, at vejlederen har indsigt i vejledningsteori, -færdigheder og -metoder. Vejledning udelukkende funderet på "fagekspertise" og/ eller praksisnær erfaringsbåren viden vil efter Lauvås og Handals mening primært rumme en videreformidling af vejlederens egen forvaltning af rollen, hvorved en kritisk forholden sig og det at tænke innovativt forhindres (Lauvås \& Handal, 1997).

Liv Sundlis forskning (2001) i praktikvejledning i norsk læreruddannelse viser ligeledes, at de studerende hæmmes mere end de vejledes til refleksion og samarbejde. Der er kun begrænset praktikvejledning i retning af at gøre studerende i stand til tage selvstændige valg eller kritisk reflektere over de mønstre, de deltager i. Refleksiv kommunikation mellem praktikvejleder og studerende findes næsten ikke, og praktikvejlederne fokuserer på handlingsniveauet og elevernes vante rutiner (Sundli, 2001). Sundlis forskning er baseret på studier af vejledning som deltagelse og samtale, hvor studerende og praktikvejledere følges.

Vejlederen skal have viden om læring og didaktik for at kunne pirre til faglig nysgerrighed. Det kan udvikle de studerendes åbenhed for kompleksitet i det professionelle arbejde og udvikle selvstændig kritisk tænkning. Her har refleksion med efterfølgende stillingtagen til en fremtidig praksis en afgørende betydning. Det fordrer, at vejlederen selv har kompetencer til at sætte ord på sin praksis og reflektere over den.

Ifølge Ulvestad (2014) bør vejledning være vidensbaseret for at undgå privatisering. Et lukket vejledningsrum med store krav til tavshedspligt og fortrolighed giver risiko for en privatisering, hvor der skabes et rum for ritualer og reproduktion af fordomme og stereotyper. Vejlederen kan tage de professionelle briller på, men også de professionelle skyklapper. Ulvestad (2014) foreslår derfor at balancere mellem og væsentliggøre de forskellige vidensområder i vejledning: forskning, faglig ekspertise/skøn samt vejledtes egenskaber, kultur og præferencer. Ligeledes må vejledning fortrinsvis baseres på professionsvejledning, hvor der gives plads til tvivl og refleksion. Derfor må vejledning indeholde centrale fagetiske og dannelsesmæssige elementer, som understøtter den vejledningssøgendes udvikling og $i$ at finde sin vej 
Paaske, Frederiksen og Mølgaard: En metasyntese af vejledning i læreruddannelser ...

(Ulvestad, 2014). Det betyder, at vejlederen skal være kompetent inden for forskellige vidensområder.

\section{Diskussion og konklusion}

Formålet med vores undersøgelse var at få viden om vejledning generelt i læreruddannelserne i Norden. Der var vanskeligheder med at finde relevante forskningsartikler med kvalitet omhandlende vejledning ud over artikler om praktikrelateret vejledning. Litteratursøgningen var begrænset til nordiske studier. De valgte databaser kan give metasyntesen en begrænsning. Søgning i flere databaser ville muligvis have givet et bredere resultat. Søgeordene for vejledning i nordiske databaser var veiledning og mentoring med trunkeringer $\left(^{*}\right)$; dermed er det forventeligt, at samtlige vejledningsområder ved læreruddannelsen som studievejledning, karrierevejledning, faglig vejledning, praktikvejledning, bachelorvejledning, opgavevejledning og pædagogisk vejledning ville komme frem i søgningen, hvis der fandtes studier inden for disse områder. I ERIC kunne søgeord som guidance og advice muligvis have givet et andet resultat.

Selvom de inkluderede artikler arbejder med forskellige metoder og derfor kan være svære at sammenligne (Bondas \& Hall, 2007; Walsh \& Downe, 2005), men vi valgte det, da metasyntesen derved kunne bygge på et bredere fundament og mere fuldstændige tolkninger (Kearney, 2001). Artiklerne er vurderet ud fra eksplicitte tjeklister, hvilket gør evidensvurderingerne transparente. Ved et kritisk blik på metasyntesens del 2 kunne artiklernes forskellige metoder og omfang (tabel 1) have været inddraget $\mathrm{i}$ den tematiske vurdering for at kvalificere tematikudvælgelsen til syntesen eksempelvis en vægtning af resultater fra de omfattende studier fra Gloppen (2013) og Ottesen \& Jahreie (2010).

Et andet blik bør falde på selve syntesen, hvor ny viden udvikles. Metasyntesen har bragt viden om, at der er forsket relativt begrænset i vejledningsområdet inden for læreruddannelsen i Norden.

Når det gælder viden om vejledning i læreruddannelser i Norden, kan vi konkludere, at denne viden primært vedrører praktikvejledning. Forskningsviden om vejledning i andre dele af uddannelsen fx faglig vejledning eller karrierevejledning er meget sparsom - nærmest helt fraværende. Interessant er det, at der ikke blev fundet artikler med evident kvalitet om forskning i faglig vejledning i læreruddannelsen i en tid, hvor meget af den nuværende 
Paaske, Frederiksen og Mølgaard: En metasyntese af vejledning i læreruddannelser ...

undervisning og selvstændige studie i læreruddannelsen tænkes understøttet af faglig vejledning, ikke mindst i det afsluttende bachelorprojekt.

I vores optik kalder det på forskning netop i faglig vejledning ud fra studerendes perspektiv, et underviserperspektiv og selvfølgelig et læringsperspektiv: Hvilke muligheder og udfordringer opleves der at være i faglig vejledning? Hvilke spor sætter den faglige vejledning i relation til den studerendes videre studie og professionelle liv? Hvilke kompetencer kræver faglig vejledning af underviseren? Kan man tænke faglig vejledning på forskellig vis? Birte Kaisers ph.d.-afhandling (Kaiser, 2011) om projektvejledning ved professionsbachelorprojekter i fysioterapeutuddannelsen er interessant. Hun er optaget af betingelserne for studerendes selvstændighed ved bachelorvejledningen og finder bl.a., at selvstændigheden er et stærkt policybegreb, som har trange kår i den konkrete bachelorvejledning.

Metasyntesen viser, at det at kunne vejlede optimalt til fortsat professionel udvikling gennem praktikvejledningen kræver langt flere kompetencer og mere viden end lærerfaglige kompetencer og det at være en god praktiker, forstået som "en god lærer for børn". Der peges på, at vejlederkompetencer handler om faglig viden om et relevant genstandsfelt, vejledningsfaglig viden, vejledningsmetodiske færdigheder samt viden om læring, pædagogik, didaktik, voksendidaktik og ikke mindst vejledningsdidaktik. En praktikvejleder er den lærerstuderendes vejleder. Det at være en god lærer for børn i skolen behøver derfor ikke at være ensbetydende med, at man er en god vejleder for voksne studerende.

Tydelige rammer, forventningsafstemning og samarbejdskontrakter i vejledning er i denne artikel mindre i fokus. Det er ikke ensbetydende med, at området ikke er væsentligt. I det hele taget er konteksten for vejledning og den kultur, vejledningen foregår i, af stor betydning. Spørgsmålet, om der er fælles begreber og fælles forståelsesgrundlag i forhold til fælles mål, er værdifuldt at beskæftige sig med.

Kompetencen til at vejlede studerende i praktikperioderne erhverves gennem praktiklæreruddannelse og praktiklærerkurser. I de sidste læreruddannelsesreformer (Uddannelses- og Forskningsministeriet, 2007; Uddannelses- og Forskningsministeriet, 2015) optræder bemærkninger om, at kommunerne skal sikre kompetente praktiklærere; idet de har en forpligtigelse til at uddanne deres praktiklærere. EVA's undersøgelse (EVA, 2012) viser, at kun $6 \%$ af praktiklærerne har en praktiklæreruddannelse, og at kun $16 \%$ af praktiklærerne har taget et praktikkursus. EVA peger på, at de studerendes udbytte af praktikperioderne vil blive styrket ved kompetent 
praktikvejledning af uddannede praktikvejledere. EVA bemærker, der er en svag tradition for uddannelse af praktikvejledere i læreruddannelsen i forhold til andre professionsuddannelser som fx sygeplejerske- og jordemoruddannelserne.

Der kan drages en parallel fra praktikvejledere for lærerstuderende til mentorer for nyuddannede lærere. Mentorkompetencer kan sidestilles med praktikvejlederkompetencer. Mentorordninger er udbredte bl.a. i forbindelse med induction-programmer i lande, hvor læreruddannelsen ikke eller kun i meget begrænset omfang indeholder praktik. Nyuddannede kan i disse lande derfor ses som stående i en lignende situation som lærerstuderende i praktik i Norden.

Mentoring defineres af Skagen som samtaler mellem en erfaren person og en mindre erfaren person med fokus på personlig udvikling (Skagen, 2013, s. 148). Mathiesen (2015) beskriver mentoring som værende enten sagsfokuseret eller personfokuseret eller begge dele. Forskning inden for vejledningsretningen mentoring og mentoruddannelser er i modsætning til vejledningsforskning inden for læreruddannelsen temmelig stærk (specielt i den internationale forskning). Her peges der på, at uddannede mentorer er det vigtigste element i kvalificering af nye lærere (Achinstein \& Atahases, 2006; Athaneses et al., 2008; Orland, 2001, Little, 1990). Mentors viden om et fagområde og almenpædagogiske problemstillinger samt mentors vejledningskompetencer indkredses i forskningen som helt centrale forudsætninger for mentors understøttelse af den nyuddannede lærer. Studier viser, at uhensigtsmæssig mentorstøtte fra ikke-kvalificerede mentorer endda kan være en medvirkende årsag til beslutning om at stoppe som lærer (Hobson et al., 2009).

Forskningen peger yderligere på, at centrale forudsætninger for at mentoren kan understøtte de nyuddannede lærere, er:

- at de er uddannede som mentorer for lærere (Hobson et al., 2009; Ingersoll \& Strong, 2011; Shockley et al., 2013; Wang et al., 2008) og dermed tænker i educative mentoring og har en bevidsthed om det bifokale blik, dvs. både blik for den nye læreres læring og professionelle vækst og blik på elevens læring og udvikling (Ginkel et al., 2016; Grudnoff, 2012)

- at de har indsigt i de værdier, holdninger og visioner, som den nyuddannede lærer har med sig fra uddannelsen (Feimann-Nemser, 1983; 2001; Ingersoll \& Strong, 2011) 
- at de har grundigt kendskab til lærerens fagområde og har den nyeste viden inden for feltet - det faglige, det fagdidaktiske og det almendidaktiske, så de kan understøtte og udfordre lærerne (Hobson et al., 2009; Ingersoll \& Strong, 2011).

I lyset af denne forskning kan man undre sig over, at der ikke satses noget mere på uddannelse af praktiklærere og ikke mindst deres vejlederkompetencer.

\section{Referencer}

Achinstein, B. and Atahaneses, 1S. Z. (2006). Focusing new teachers on diversity and equity: toward a knowledge base for mentors. Teaching and Teacher Education, 21(7), s. 843-862 https://doi.org/10.1016/j.tate.2005.05.017

Athaneses, S.Z., Abrahams, J., Jack G., Johnson, V., Kwock, S., Mc Curdy, J., Riley, 1-, Totaro, S. (2008). Curriculum for mentor development: problems and promise in the work of new teacher induction leaders. Journal of curriculum studies, 2008 Vol 40, No. 6: s. 743-770. DOI:10.1080/00220270701784319

Atjonen, P. (2012). Student teachers' outlooks upon the ethics of their mentors during teaching practice. Scandinavian Journal of Educational Research, Bind 56 (Hæfte 1) DOI: 10.1080/00313831.2011.567395

Billhult, A., \& Gunnarsson, R. (2014). Spørgeskemaundersøgelser. I M. Henricson (Ed.), Videnskabelig teori og metode: Fra idé til eksamination. Kbh.: Munksgaard.

Bjørndal, C.R.P. (2008). Bak veiledningens dør: Symmetri og asymmetri $i$ veiledningssamtaler. Tromsø: Universitet i Tromsø.

Bjørndal, C.R.P. (2010). Kvalitet, Kompetens Och Kundskapsutveckling. Jönköping Sverige.

Bondas, T., \& Hall, E.O.C. (2007). Challenges in approaching metasynthesis research. Qualitative Health Research, Bind 17 (Hæfte 1), s. 113-121.

DOI: https://doi-org.ez-aaa.statsbiblioteket.dk:12048/10.1177/1049732306295879

Borgen, W., \& Hiebert, B. (2002). Technical and vocational education and training in the 21st century. New roles and chanllenges for guidance and counselling. United Nations' Educational, Scientific and Cultural Organizition, Unesco.

Borgen, W., \& Hiebert, B. (2006). Career guidance and counselling for youth: What adolescents and young adults are telling us? International Journal for the Advancement of Counselling, 28 December 2006, s. 389-400. DOI https://doi-org.ez-aaa.statsbiblioteket. dk:12048/10.1007/s10447-006-9022-5

Chin, T. \& Benne, K. (1969) General strategies for effecting changes in human system. I W. Bennis,

K. Benne \& R. Chin (red.) The planning of change, (2nd ed. s. 32-59). New York: Rinnehart \& Winston.

Dahler-Larsen, P. (2008). At fremstille kvalitative data. Odense: Syddansk Universitetsforlag. Dysthe, O. (red.) (2003). Dialog, samspil og læring. Århus: Klim.

Eriksson, A. (2013). Positive and negative facets of formal group mentoring: Preservice teacher perspectives. Mentoring \& Tutoring, Bind 21 (Hæfte 3). http://dx.doi.org.ez-aaa. statsbiblioteket.dk:2048/10.1080/13611267.2013.827834

EVA (2012). Læreruddannelsens faglige kvalitet. www.eva.dk 
Paaske, Frederiksen og Mølgaard: En metasyntese af vejledning i læreruddannelser ...

Feiman-Nemser, S. (1983). Learning to teach. I L.S. Shulman \& G. Sykes (Eds.), Handbook of teaching and policy (s. 150-170). New York: Longman.

Feiman-Nemser, S. (2001). Helping novices learn to teach: lessons from an exemplary support teacher. Journal of Teacher Education, 52 (1), s. 17-30.

Feltham, C. (2013). Counselling and counselling psychology: A critical examination. Manchester: PCCS Books. http://dx.doi.org.ez-aaa.statsbiblioteket.dk:2048/10.1080/13642537.2013.850 211

Frederiksen, L.L. (2013). Flertydighed I professional udvikling- et oplæg til diskussion. I M.H. Beck, L.L. Frederiksen \& T. Iskov, (2013). Undervisning i læreruddannelsen, et oplæg til grundlagsdiskussioner. Systime.

Ginkel, G.van, Oobekkink, H., Meijer, P.C., \& Verloop, N. (2016). Adapting mentoring to individual differences in novice teacher learning: the mentor's viewpoint. Teachers and Teaching, 22(2), 198-218. http://dx.doi.org.ez-aaa.statsbiblioteket.dk:2048/10.1080/1354060 2.2015.1055438

Gloppen, B.H. (2013). Trepartssamtalen - en arena for å styrke samspillet mellom høgskolens undervisning og praksis? eksempler fra lærerutdanningen. Uniped, Bind 2 (Hæfte 1), s. 88-101. DOI: 10.18261/issn.1893-8981

Grudnoff, L. (2012). All's well? New Zealand beginning teachers'experience of induction provision in their first six months in school. Professional Development in Education, 38(3), 471-485. http://dx.doi.org.ez-aaa.statsbiblioteket.dk:2048/10.1080/19415257.2011.636894

Heikkinen, H.L.T., Jokinen, J.H. \& Tynjälä (2008). Reconceptualising Mentoring as a Dialogue. I G. Fransson, Newly Qualified Teachers in Northern Europe. University of Gävle.

Hobson, A.J., Ashby, P., Malderez, A. \& Tomlinson, P.D. (2009). Mentoring beginning teachers: What we know and what we don't. Teacher and teacher Education, 2009. Vol. 25, 207-216. https://doi.org/10.1016/j.tate.2008.09.001

Ingersoll, R. \& Strong, M. (2011). The Impact of Induction and mentoring Programs for Beginning

Teachers: A Critical Review of the Research. Review of Educational Research, 2011. Vol. 81. Is 2, 201-230. DOI: https://doi-org.ez-aaa.statsbiblioteket.dk:12048/10.3102/00346543114033 23

Jank \& Meyer, H. (1997). Didaktikkens centrale spørgsmål. I M. Uljens (Ed.): Didaktik- teori, refleksion og praktik. Lund: Studentlitteratur.

Kaiser, B. (2011). Projektvejledning?. Ph.d. afhandling, Danmarks Pædagogiske Universitetsskole, Aarhus Universitet.

Kaiser, B. (2012). Vejledning som facilitering af læring. Paper til Konference, oktober, 2012, på VIA: Nordisk Netværk for Professionsforskning.

Kearney, M.H. (2001). New directions in grounded formal theory. I Schreiber, \& Stern (Eds.), Using grounded theory in nursing (s. 227-246). New York: Springer Publishing Company.

Korthagen, F.A.J. \& Wubbels, T. (1995). Characteristics of Reflective Practitioners towards an operationalization of the concept of reflection. Teachers and Teaching: theory and practice, Vol.1, No. 1, 1995.

Kvale, S., \& Brinkmann, S. (2009). Interview: Introduktion til et håndværk (2. udgave ed.). Kbh.: Hans Reitzel.

Lauvås, P., \& Handal, G. (1997). Vejledning og praktisk fagteori (1. udgave ed.). Århus: Klim.

Levack, W.M.M. (2012). The role of qualitative metasynthesis in evidence-based physical therapy. Physical Therapy Reviews, 17(6), s. 390-397.

Little, J.W. (1990). The mentor phenomenon and the social organization of teaching. I D. Courtney Cazden (Ed.): Review of research in education: s. 297-351. Washíngton DC: American Educational Research Association 
Paaske, Frederiksen og Mølgaard: En metasyntese af vejledning i læreruddannelser ...

Løve, T. (1985). Vejleder: En person, en position, en profession, en rolle. Fredensborg: Studie og Erhverv.

Løve, T. (2005). Vejledning ansigt til ansigt: Teorier og metoder $i$ den individuelle vejledning (2. udgave ed.). Fredensborg: Studie og Erhverv.

Mathisen, P. (2015) Mentor. Mentoring I teori og praksis. Fakbokforlaget.

Nilssen, V. (2010a). Encouraging the habit of seeing in student teaching. Teaching and Teacher Education, Bind 26 (Hæfte 3) s. 591-598. https://doi.org/10.1016/j.tate.2009.09.005

Nilssen, V. (2010b). Guided planning in first-year student teachers' teaching. Scandinavian Journal of Educational Research, Bind 54 (Hæfte 5) s. 431-449. http://dx.doi.org.ez-aaa.statsbiblioteket.dk:2048/10.1080/00313831.2010.508909

Ohnstad, F., \& Munthe, E. (2008). Ensomme svaler? en studie av praksisskolelæreres rapportering om identitet, kollektivitet og gjennomføring av praksisopplæringsperioder. Norsk Pedagogisk Tidsskrift, Bind 92 (Hæfte 6) s. 471-483. DOI: 10.18261/issn.1504-2987

Orland, L. (2001). Reading a mentoring situation: One aspect of learning to mentor. Teaching and Teacher Education, 17(1), s. 75-88. https://doi.org/10.1016/S0742-051X(00)00039-1

Ottesen, E., \& Jahreie, C. (2010). Construction of boundaries in teacher education: Analyzing student teachers' accounts. Mind, Culture and Activity, Bind 17 (Hæfte 3), s. 212-234. http://dx.doi.org.ez-aaa.statsbiblioteket.dk:2048/10.1080/10749030903314195

Plant, P. (2014). Undervisningsbaseret vejledning. UddannelsesGuiden, november 2007

Peavy, R.V. (2006). Konstruktivistisk vejledning. Studie \& erhverv

Paaske, K.A. (2010). Vejledning til fremtiden: Et studium af e-mailvejledning $i$ studievalgscentre. Ph.d.-afhandling. Danmarks Pædagogiske Universitetsskole.

Roecker, C. (2012). Hierarchy of evidence awareness saves time. Journal of the American Chiropractic Association, s. 7-10.

Rønnestad. M.H. (2008). Profesjonell utvikling. I A Molander \& L.I. Terum, (red.), Profesjonsstudier. Oslo: Universitetsforlaget

Sandelowski, M., \& Barroso, J. (2007). Handbook for synthesizing qualitative research. New York, Springer.

Schnack, K. (1994). Didaktisk forskning i Danmark. Dansk Pædagogisk Tidsskrift, 42(4), s. 175-182.

Shockley, R., Watlington, E. \& Felsher, R. (2013). Out on a Limb: The Efficacy of Teacher Induction in Secondary Schools. NASSP Bulletin, 2013. Vol.97, 350-377. DOI: https://doiorg.ez-aaa.statsbiblioteket.dk:12048/10.1177/0192636513510595

Skagen, K. (2013). I veiledningens landskap. CAPPELEN DAMM AKADEMISK

Smeby, J.C. (2008). "Studiekvalitet, praksiskvalitet og yrkesrelevans". I P. Haug (red.). Kvalifisering til læraryrket. Norge: Abstrakt Forlag.

Solstad, A.G. (2010). Praksisnær teori og teorinær praksis - den nødvendige relasjonen. Norsk Pedagogisk Tidsskrift, Bind 94 (Hæfte 3), s. 203-218. DOI: 10.18261/issn.1504-2987

Solstad, A.G. (2013). Profesjonsorientert refleksjon i praksisopplæringen - en utfordring for lærerutdanningen. Norsk Pedagogisk Tidsskrift, Bind 97 (Hæfte 2) s. 97-108. DOI: 10.18261/ issn.1504-2987

Sundli, Liv (2001). Veiledning i lærerutdanningens praksis - mellem refleksjon og kontroll. Ph.d. -afhandling, Danmarks Pædagogiske Universitet, København.

Tanggaard, L. (2015). Kvalitet i kvalitative studier. I S. Brinkmann, \& L. Tanggaard (Eds.), Kvalitative metoder: En grundbog (2nd ed., s. 521-531). Kbh.: Hans Reitzel.

Thomsen, C. \& Dahlerup, J.F. (2008). Kort indføring i evidens. Projektafdelingen for Det Nye Universitetshospital, Region Midtjylland; Medicinsk afdeling V, Århus.

Tingleff E.B., Rossen, C.B. \& Buus, N. (2010). A qualitative metasynthesis of psychiatric nurses' experiences of the transition from being student to being newly qualified. Nordic Journal of Nursing Reasearch \& Clinical Studies /Vård i Norden, 30(1), s. 45-47 
Paaske, Frederiksen og Mølgaard: En metasyntese af vejledning i læreruddannelser ...

Uddannelses- og Forskningsministeriet. (2007). Bekendtgørelse om uddannelsen til professionsbachelor som lærer i folkeskolen. BEK nr 219 af 12/03/2007. Retrieved 26.06.17 from https:// www.retsinformation.dk/Forms/R0710.aspx?id=25302

Uddannelses- og Forskningsministeriet. (2015). Bekendtgørelse om uddannelsen til professionsbachelor som lærer i folkeskolen BEK nr 1068 af 08/09/2015. Retrieved 9.12.2016 from https:// www.retsinformation.dk/forms/R0710.aspx?id=174218

Ulvestad, A.K. (2014). Den umulige profession. I A.K. Ulvestad, \& F.U. Kärki (Eds.), Flerstemmig vejledning. s. 29-48. Aarhus. Klim.

Undervisningsministeriet. (2003). Vejledningsreformen. Retrieved 9.12.2016 from http://pub. uvm.dk/2003/vejledning/hel.htm

VIA University College. (2015). Studieordninger på læreruddannelsen - VIA UC. Retrieved 9.12.2016 from http://www.via.dk/uddannelser/paedagogik-og-laering/laerer/studieordninge

Wiberg, M. (2017). Kontinental didaktik og angelsaksisk curriculumtænkning. Liv i Skolen, 19(1), 14-23.

Walsh, D., \& Downe, S. (2005). Meta-synthesis method for qualitative research: A literature review. Journal of Advanced Nursing, Bind 50 (Hæfte 2) s. 204-211. DOI: 10.1111/j.13652648.2005.03380

Wang, J. \& Odell, S.J. (2007): An alternative conception of mentor-novice relationships: Learning to teach in reform-minded ways as a context. Teaching and Teacher Education (2007) Volume: 23, Issue: 4, s. 473-489. https://doi.org/10.1016/j.tate.2006.12.010.

Wang, J., Odell, S.J. \& Sharon A.S. (2008). Effects of teachers' induction on beginning teachers teaching. Journal Teacher and Teacher Education, 2008. Vol.59. Is. 2, 132-152.

Willman, A., \& Stoltz, P. (2014). Metasyntese. I M. Henricson (Ed.), Videnskabelig teori og metode: Fra idé til eksamination .1. udgave ed., s. 473-485. Kbh.: Munksgaard.

Åberg, K. (2009). Andledning til handledning. skolledares perspektiv på grupphandledning. Högskolan för lärande och kommunikation i Jönköping. 